\title{
THREE-STEP RESONANCE ENERGY TRANSFER IN INSULIN AMYLOID FIBRILS
}

\author{
(D) Uliana Tarabara ${ }^{1 *}$, Mykhailo Shchuka ${ }^{1}$, Kateryna Vus $^{1}$, (D) Olga Zhytniakivska ${ }^{1}$, \\ (D)Valeriya Trusova ${ }^{1}$, (Dalyna Gorbenko ${ }^{1}$, Nikolai Gadjev², Todor Deligeorgiev ${ }^{2}$ \\ ${ }^{I}$ Department of Medical Physics and Biomedical Nanotechnologies, V.N. Karazin Kharkiv National University \\ 4 Svobody Sq., Kharkiv, 61022, Ukraine \\ ${ }^{2}$ Faculty of Chemistry and Pharmacy, Sofia University, "St. Kliment Ohridski" 1, \\ blv. J. Bourchier, Sofia, 1164, Bulgaria \\ *E-mail: uliana.tarabara@gmail.com \\ Received 15 October 2019, revised November 6, 2019; accepted November 11, 2019
}

\begin{abstract}
The applicability of the three-step Förster resonance energy transfer (FRET) to detection of insulin amyloid fibrils was evaluated, using the chromophore system, containing Thioflavin T (ThT), 4-dimethylaminochalcone (DMC), and two squaraine dyes, referred to here as SQ1 and SQ4. The mediator chromophore DMC was found to enhance the fluorescence intensity of the terminal acceptor, SQ1, excited at $440 \mathrm{~nm}$ (at the absorption maximum of the principal donor, ThT), in fibrillar insulin compared to the system without DMC, providing the evidence for the cascade energy transfer in the chain $\mathrm{ThT} \rightarrow \mathrm{DMC} \rightarrow \mathrm{SQ} 4 \rightarrow \mathrm{SQ} 1$. Furthermore, the resulting Stokes shift in the four-chromophore system was $240 \mathrm{~nm}$, as compared to $45 \mathrm{~nm}$ for the fibril-bound ThT, suggesting that higher signal-to-noise ratio is the advantage of amyloid fibril detection by multistep FRET. The maximum efficiencies of energy transfer in the insulin fibrils estimated from the quenching of the donor fluorescence in the presence of acceptor for the donor-acceptor pairs ThT-DMC, DMCSQ4 and SQ4-SQ1 were 40\%, 60\% and 30\% respectively, while negligible FRET occurred in the non-fibrillized protein. The most pronounced differences between fibrillar and non-fibrillized insulin were observed in the 3D fluorescence spectra. Specifically, two intensive spots centered at the emission wavelengths $\sim 650 \mathrm{~nm}$ (SQ4) and $\sim 685 \mathrm{~nm}$ (SQ1) were revealed at the excitation wavelength $\sim 440 \mathrm{~nm}$ in the 3D patterns of insulin amyloid aggregates. In contrast, in the case of the non-fibrillized protein, the barely noticeable spots centered at the same wavelengths, as well as higher fluorescence intensities at the excitation above $550 \mathrm{~nm}$ were observed, suggesting the predominant impact of the direct excitation of SQ1 and SQ4 on their fluorescence responses. The inter-chromophore distances calculated from the experimental values of the energy transfer efficiency assuming the isotropic rotation of the dyes, were found to be 2.4, 4.5 and $4.3 \mathrm{~nm}$ for the ThT-DMC, DMC-SQ4 and SQ4-SQ1 pairs, respectively, revealing the different fibril binding sites for the examined dyes. The quantum-chemical calculations and simple docking studies provided evidence for the SQ1, SQ4 and ThT, DMC binding to the wet and dry interface of the insulin amyloid protofilament, respectively. The dye-protein complexes are likely to be stabilized by the hydrophobic, van der Waals, aromatic and electrostatic interactions. In summary, the above technique based on the multistep FRET can be employed for the identification and characterization of amyloid fibrils in vitro along with the classical ThT assay, allowing the increase of the amyloid detection sensitivity and lowering the probability of the pseudo-positive result. The applicability of the multistep FRET for amyloid visualization in vivo can be also tested by the involvement of the nearinfrared fluorescent dyes to the cascade.
\end{abstract}

KEYWORDS: cascade resonance energy transfer, 4-dimethylaminochalcone, fibrillar insulin, squaraine dyes, Thioflavin T.

During the past decade a phenomenon of the Förster resonance energy transfer (FRET) has emerged as an extremely useful tool for retrieving information about proximity relationships and structural dynamics of biological macromolecules and their assemblies [1-3]. Due to a strong dependence of the energy transfer efficiency on the donor-acceptor distance, FRET is particularly useful while determining the intra- and intermolecular distances on a nanometer scale [4,5]. Although most FRET studies involve analysing a conventional one-step energy transfer, a multistep FRET (msFRET) has been attracting much attention in recent years [6-10], inspired by the natural photosynthetic systems containing several lightharvesting complexes that efficiently transfer the absorbed energy between a number of chromophores $[11,12]$. The energy transfer within multiple chromophore systems usually follows a cascade route, moving from an initial donor chromophore through the intermediate donors/acceptors onto a final acceptor chromophore [6-10,13]. The multistep FRET offers several advantages over the one-step FRET: i) a higher efficiency of long-range transfer [14]; ii) a larger Stokes shift $[13,15]$; iii) the possibility to monitor inter- and intramolecular interactions beyond the range 1-10 $\mathrm{nm}[16]$; and iv) an extended excitation wavelength range for fluorescence lifetime measurements [14]. As a result, the cascade, or multistep FRET appeared to be especially useful in developing molecular photonic wires and light harvesting systems [6$8,17]$. Most of such artificial systems are devised through synthesizing the arrays of covalently linked chromophores with a specific design to ensure large collection efficiencies, as well as fast and efficient energy migration. By analogy with the natural antenna, the majority of these systems are based on the porphyrin pigments $[13,15,18,19]$. Another application of msFRET involves the DNA photonic wires self-assembled around $\mathrm{CdSe} / \mathrm{ZnS}$ semiconductor quantum dots acting as a nanoscaffold and a FRET donor to a series of DNA-intercalating dyes [17]. More importantly, the msFRET systems are effectively used in biosensors for sensitive detection of multivalent complexation [20], protein labeling [15], genotyping of single nucleotide polymorphism [21], DNA sequencing [16], estimating the stoichiometry of protein complexes [22], determination of the tumor necrosis factor [23] and analysis of multiprotein interactions in living cells [24], to name only a few. 
Remarkably, the multistep FRET have been successfully employed for the detection of a specific type of protein aggregates - amyloid fibrils, whose formation is associated with the pathogenesis of neurodegenerative diseases, type II diabetes, systemic amyloidosis, etc. [25]. More specifically, it was demonstrated that amyloid-sensing potential of the classical amyloid marker, Thioflavin $\mathrm{T}$, can be reinforced by its implication as a primary donor in the two-step energy transfer process [25], creating a background for application of amyloid nanostructures as a molecular framework for controlled positioning of a multitude of chromophores communicating via the multi-step FRET in photonic devices. To the best of our knowledge, so far, the potential of amyloid-scaffolded msFRET remains poorly investigated. In view of this, the aim of the present study was to assess the insulin amyloid-sensing potential of the three-step Förster resonance energy transfer using the four-chromophore system containing a benzothiazole dye Thioflavin T, 4dimethylaminochalcone and two squaraine dyes, SQ1 and SQ4.

\section{THEORY}

Förster resonance energy transfer is a long-range electrodynamic interaction of two chromophores: the excited donor and the ground-state acceptor, as a result of which the energy of the excited donor is non-radiatively transferred to the acceptor [26]:

$$
D^{*}+A \rightarrow D+A^{*}
$$

The main prerequisites for FRET include i) the overlap between emission spectrum of a donor and absorption spectrum of an acceptor and ii) the donor-acceptor separation falling in the range 0-10 $\mathrm{nm}$. Each donor-acceptor pair can be characterized by the three parameters: $k_{t}$, the energy transfer rate; $r$, the distance between chromophores; and $R_{0}$, the Förster radius, related by the equation [27]:

$$
k_{t}(r)=\frac{1}{\tau_{D}}\left(\frac{R_{0}^{6}}{r}\right)
$$

where $\tau_{D}$ is the donor fluorescence lifetime in the absence of acceptor. The energy transfer efficiency $E$, i.e. the probability that the excited donor will transfer energy to the ground-state acceptor, can be written as:

$$
E=\frac{k_{t}}{k_{t}+\tau_{D}^{-1}}=\frac{R_{0}^{6}}{R_{0}^{6}+r^{6}}
$$

The Förster radius, i.e. the donor-acceptor distance at which the energy transfer efficiency equals $50 \%$, is given by:

$$
R_{0}=979\left(\kappa^{2} n_{r}^{-4} Q_{D} J\right)^{1 / 6}, J=\int_{0}^{\infty} F_{D}(\lambda) \varepsilon_{A}(\lambda) \lambda^{4} d \lambda / \int_{0}^{\infty} F_{D}(\lambda) d \lambda
$$

where $J$ is the overlap integral; $F_{D}(\lambda)$ is the donor fluorescence intensity, $\varepsilon_{A}(\lambda)$ is the acceptor molar absorbance at the wavelength $\lambda, n_{r}$ is the refractive index of the medium; $Q_{D}$ is the donor quantum yield; $\kappa^{2}$ is the orientation factor defined as:

$$
\left.\kappa^{2}=\left(\overrightarrow{e_{D}}, \overrightarrow{e_{A}}\right)-3\left(\overrightarrow{e_{D}}, \overrightarrow{e_{D A}}\right)\left(\overrightarrow{e_{D A}}, \overrightarrow{e_{A}}\right)\right)^{2}
$$

where $\overrightarrow{e_{D}}, \overrightarrow{e_{A}}$ are the unit transition vectors of the donor and acceptor respectively; $\overrightarrow{e_{D A}}$ is the unit vector drawn from the donor to the acceptor [28]. The orientation factor may take a value from 0 to 4 , but usually $R_{0}$ is calculated with $\kappa^{2}=2 / 3$ (when the orientations of the donor emission and acceptor absorption transition dipoles randomize during the fluorescence lifetime). The uncertainty in $\kappa^{2}$ is the main limitation of the FRET technique resulting in the distance estimation error up to $35 \%$ ) [28-30]. This problem can be partly circumvented through narrowing the $\kappa^{2}$ limits by measuring the anisotropy of donor and acceptor [28, 29, 31].

A

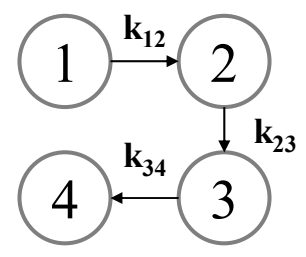

B

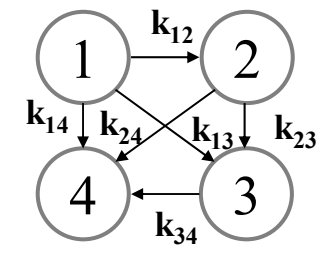

Fig. 1. A four-chromophore system for energy transfer: (A) three-step FRET (energy is transferred from chromophore 1 to 4 via 2 and 3 ), and (B) all possible pathways of the energy transfer.

In the present study, the FRET system consisting of four chromophores is considered. There are many scenarios for this system and the two most important of them are illustrated in Fig.1. Let us designate the chromophores 1, 2, 3, and 4 as D1, D2, D3, and A3, respectively. 
In the case A (Fig. 1A), it is shown that the total three-step FRET efficiency $(E)$ measured from the enhancement of the A3 emission is the product of efficiencies for each of FRET steps [33]:

$$
E=E_{12} E_{23} E_{34}
$$

where $E_{12}, E_{23}$ and $E_{34}$ are energy transfer efficiencies from D1 to D2, from D2 to D3 and from D3 to A3, respectively.

In the case B (Fig. 1B), the concentration of chromophores in the excited state can be described by the following differential equations:

$$
\begin{aligned}
& \frac{d\left[D_{1}^{*}\right]}{d t}=-\left[D_{1}^{*}\right]\left(k_{12}+k_{13}+k_{14}+\tau_{D 1}^{-1}\right) \\
& \frac{d\left[D_{2}^{*}\right]}{d t}=-\left[D_{2}^{*}\right]\left(k_{23}+k_{24}+\tau_{D 2}^{-1}\right)+\left[D_{1}^{*}\right] k_{12} \\
& \frac{d\left[D_{3}^{*}\right]}{d t}=-\left[D_{3}^{*}\right]\left(k_{34}+\tau_{D 3}^{-1}\right)+\left[D_{1}^{*}\right] k_{13}+\left[D_{2}^{*}\right] k_{23} \\
& \frac{d\left[A_{3}^{*}\right]}{d t}=-\left[A_{3}^{*}\right] \tau_{A 3}^{-1}+\left[D_{1}^{*}\right] k_{14}+\left[D_{2}^{*}\right] k_{24}+\left[D_{3}^{*}\right] k_{34}
\end{aligned}
$$

The energy transfer efficiency measured through monitoring the increase in acceptor fluorescence is given by [33]:

$$
\begin{gathered}
E=\frac{I_{A}}{\tau_{A}} \\
I_{A}=\frac{1}{n_{0}} \int_{0}^{\infty}\left[A_{3}^{*}\right](t) d t
\end{gathered}
$$

where $n_{0}=\left[D_{1}^{*}\right](t=0), \quad \tau_{A} \quad$ is the acceptor lifetime. Assuming that $\left[D_{1}^{*}\right](t=0)=1$, and $\left[D_{2}^{*}\right](t=0)=\left[D_{3}^{*}\right](t=0)=\left[A_{3}^{*}\right](t=0)=0$, from equations (10) and (12) one obtains:

$$
I_{3}=\frac{k_{12} k_{23} k_{34}+k_{13} k_{34}\left(k_{23}+k_{24}+\tau_{D 2}^{-1}\right)+k_{12} k_{24}\left(k_{34}+\tau_{D 3}^{-1}\right)+k_{14}\left(k_{23}+k_{24}+\tau_{D 2}^{-1}\right)\left(k_{34}+\tau_{D 3}^{-1}\right)}{\left(k_{12}+k_{13}+k_{14}+\tau_{D 1}^{-1}\right)\left(k_{23}+k_{24}+\tau_{D 2}^{-1}\right)\left(k_{34}+\tau_{D 3}^{-1}\right) \tau_{A 3}^{-1}}
$$

Using the formula for the energy transfer efficiency within one donor-acceptor pair (Eq. 11), the $E$ value in the threestep FRET can be written as follows:

$$
E=E_{12}^{\prime} E_{23}^{\prime} E_{34}+E_{13}^{\prime} E_{34}+E_{12}^{\prime} E_{24}^{\prime}+E_{14}^{\prime}
$$

where $E_{i j}^{\prime}$ is the energy transfer efficiency from the donor $i$ to the acceptor $j$ in the presence of the parallel energy transfer from the donor $i$ to other acceptors.

\section{EXPERIMENTAL SECTION}

Materials

Bovine insulin, dimethyl sulfoxide (DMSO), Tris, thioflavin T (ThT) and phosphotungstic acid hydrate for electron microscopy were purchased from Sigma. 4-dimethylaminochalcone (DMC) was from Signe (Latvia). The squaraine dyes SQ1 and SQ4 were synthesized in the University of Sofia, Bulgaria. All other reagents were used without further purification.

\section{Preparation of working solutions}

The insulin stock solution $(10 \mathrm{mg} / \mathrm{ml})$ was prepared in $10 \mathrm{mM}$ glycine buffer $(\mathrm{pH} 2.0)$. The reaction of the protein fibrillization was conducted at $37^{\circ} \mathrm{C}$ in the above buffer under constant agitation on the orbital shaker. The kinetics of amyloid formation was monitored using the Thioflavin T assay [34]. Hereafter, the fibrillar protein and its non-fibrillized counterpart (the insulin solution in glycine buffer that was not subjected to agitation) are denoted as InsF and InsN, respectively.

The dyes stock solutions were prepared in DMSO (SQ1 and SQ4) and ethanol (DMC), while ThT was dissolved in $10 \mathrm{mM}$ Tris buffer ( $\mathrm{pH}$ 7.4). The fluorimetric measurements were carried out in $10 \mathrm{mM}$ Tris-HCl buffer ( $\mathrm{pH}$ 7.4).

For the transmission electron microscopy assay, a $10 \mu 1$ drop of the protein solution was applied to a carbon-coated grid and blotted after $1 \mathrm{~min}$. A $10 \mu \mathrm{l}$ drop of $1.5 \%$ (w/v) phosphotungstic acid solution was placed on the grid, blotted 
after $30 \mathrm{~s}$, and then washed 3 times by deionized water and air dried. Then the grids were viewed with the EM-125 electron microscope (Selmi, Ukraine).

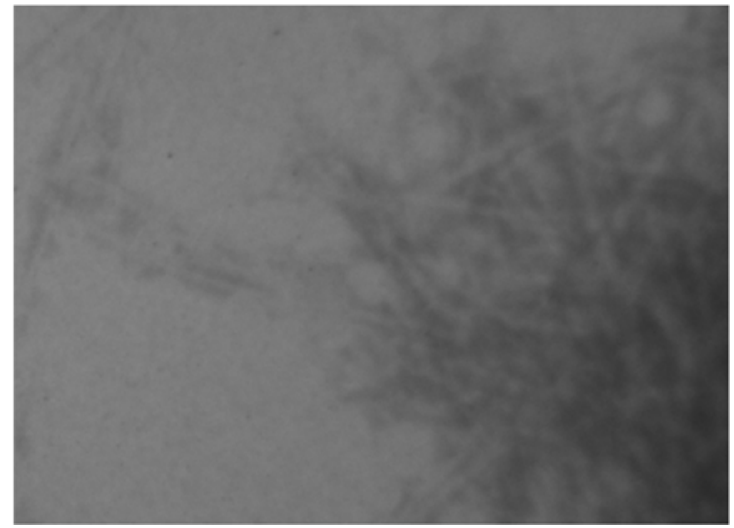

Fig. 2. Transmission electron microscopy photograph of the insulin amyloid fibrils.

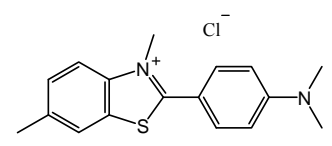

ThT

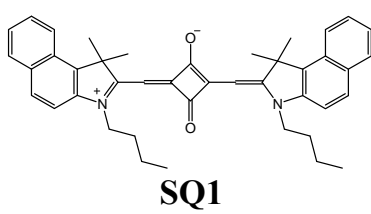

Fig. 3. Chemical structures of the employed donor and acceptor fluorophores.

\section{Spectroscopic measurements}

The absorption spectra of the examined dyes were recorded with the spectrophotometer Shimadzu UV-2600 (Japan) at $25{ }^{\circ} \mathrm{C}$. The dye concentrations were determined spectrophotometrically using the extinction coefficients $\varepsilon_{418}^{\text {Ethanol }}=3.46 \cdot 10^{4} \mathrm{M}^{-1} \mathrm{~cm}^{-1}, \quad \varepsilon_{662}^{\text {DMSO }}=2.3 \cdot 10^{5} \mathrm{M}^{-1} \mathrm{~cm}^{-1}, \varepsilon_{641}^{\text {DMSO }}=4.21 \cdot 10^{5} \mathrm{M}^{-1} \mathrm{~cm}^{-1}$ and $\varepsilon_{412}^{\text {water }}=3.6 \cdot 10^{4} \mathrm{M}^{-1} \mathrm{~cm}^{-1}$ for $\mathrm{DMC}$, SQ1, SQ4 and ThT, respectively. Steady-state fluorescence spectra were recorded with RF6000 spectrofluorimeter (Shimadzu, Japan). Fluorescence measurements were performed at $25{ }^{\circ} \mathrm{C}$ using $10 \mathrm{~mm}$ pathlength quartz cuvettes. Fluorescence spectra were recorded within the range $460-820 \mathrm{~nm}$ with the excitation wavelength $440 \mathrm{~nm}$. The excitation and emission slit widths were set at $10 \mathrm{~nm}$.

The efficiency of energy transfer was determined from the quenching of the donor fluorescence in the presence of acceptor [29]:

$$
E=1-\frac{I_{D A}}{I_{D}}
$$

where $I_{D}, I_{D A}$, are the donor fluorescence intensities in the absence and in presence of the acceptor, respectively. The donor fluorescence intensities measured in the presence of acceptor were corrected for inner filter effect using the following coefficients [29]:

$$
k=10^{\left(A_{a}^{e x}+A_{a}^{e m}\right) / 2}
$$

where $A_{a}^{e x}, A_{a}^{e m}$ are the acceptor optical densities at the donor excitation and emission wavelengths, respectively. The critical distance of energy transfer was calculated from eq. (4) using the Mathcad 15.0 software.

\section{Molecular docking study}

The molecular docking was carried out to ascertain the putative sites for the dye binding to insulin fibrils. The model of fibrillar insulin was taken from http://people.mbi.ucla.edu/sawaya/jmol/fibrilmodels/ [35]. The structures of the dyes were optimized using the semiempirical method PM6 (MOPAC2016 version18.012L) [36]. The top 10 conformations obtained with the PatchDock algorithm were then refined by the FireDock software [37]. The docked complexes were visualized by the Visual Molecular Dynamics (VMD) software.

\section{Quantum-chemical calculations}

Using the MOPAC2016 software, the geometry optimization of the dye conformations was performed, followed by the calculation of the quantum-chemical characteristics, such as: the solvent-accessible area $(C A)$; molecular volume ( $C V$ ); energy of the highest occupied ( $\left.E_{\text {Номо }}\right)$ and lowest unoccupied ( $\left.E_{L U M O}\right)$ molecular orbitals; molecular length $(L$ ), height $(H)$ and width $(W)$; ground state dipole moment $\left(\mu_{g}\right)$ and molecular weight ( $M$. wt. ). The $\log P$, a compound lipophilicity, was obtained using the ALOGPS 2.1 program (http://www.vcclab.org/lab/alogps/) [38]. All the calculated parameters are presented in Table 3.

\section{RESULTS AND DISCUSSION}

The ensemble of four dyes including the classical amyloid marker ThT (donor D1), chalcone dye DMC (acceptor A1 for ThT and donor D2), squaraine dyes SQ4 (acceptor A2 for DMC and donor D3) and SQ1 (acceptor A3) were selected to study the msFRET applicability to amyloid detection based on our previous results [25]. 
At the first step of the study we addressed the question of how the fluorescence of the terminal acceptor (SQ1) is sensitized by the other donors/acceptors of the energy transfer chain. To this end, the fluorescence spectra of the SQ1protein mixtures were measured with the excitation wavelength $440 \mathrm{~nm}$ (Fig. 4) that was chosen based on the spectral characteristics of the primary donor, ThT. The fluorescence intensity of SQ1 in the emission maximum (680 nm) did not exceed 1000 a.u. in the presence of fibrillar insulin (InsF). The addition of SQ4 (D3) into this system led to some decrease in SQ1 (A3) fluorescence, as well as to the appearance of the SQ4 fluorescence band. This implies that the expected enhancement of acceptor fluorescence does not occur at this stage, presumably because of relatively low fluorescence signal from SQ4 under the employed experimental conditions. At the same time, no SQ1 and SQ4 fluorescence was observed in the presence of the control protein (InsN). However, the subsequent addition of ThT resulted in the pronounced fluorescence increase in InsF, indicating that the energy is transferred from ThT to the squaraines. There are two possibilities by which such energy transfer may occur, the parallel pathway (ThT $\rightarrow$ SQ4 and ThT $\rightarrow$ SQ1) and the sequential one $(\mathrm{ThT} \rightarrow \mathrm{SQ} 4 \rightarrow \mathrm{SQ} 1)$. Moreover, when the FRET chain was complemented by DMC serving as a bridge between ThT and SQ4, the squaraine fluorescence showed a further enhancement increasing with the elevation of DMC concentration (Fig. 4A,B). It is interesting to note that squaraine peaks emerging in the presence of DMC were observed also for InsN with SQ4 fluorescence signal being higher than that of SQ1, while in the absence of the mediator SQ1 and SQ4 fluorescence was negligibly small. The excitation spectra measured at the emission wavelength $720 \mathrm{~nm}$ at the highest DMC concentration also are indicative of the marked difference between the InsF and InsN (Fig. 4C). The squaraine peaks are clearly resolved in these spectra at $637 \mathrm{~nm}$ for SQ4, and $676 \mathrm{~nm}$ for SQ1, in the presence of the fibrillar insulin, while small hypsochromic shifts $c a .8$ and $3 \mathrm{~nm}$ for SQ4 and SQ1, respectively, along with significantly lower fluorescence intensities were observed for the control non-fibrillized protein.

A

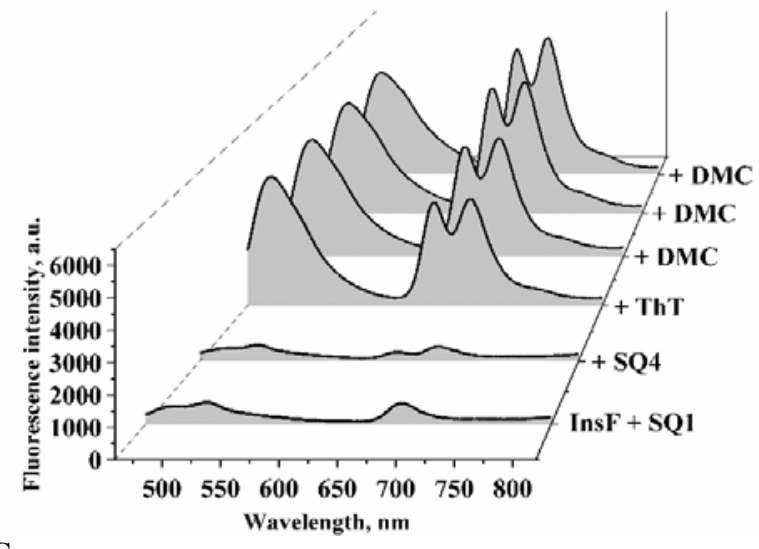

$\mathrm{C}$

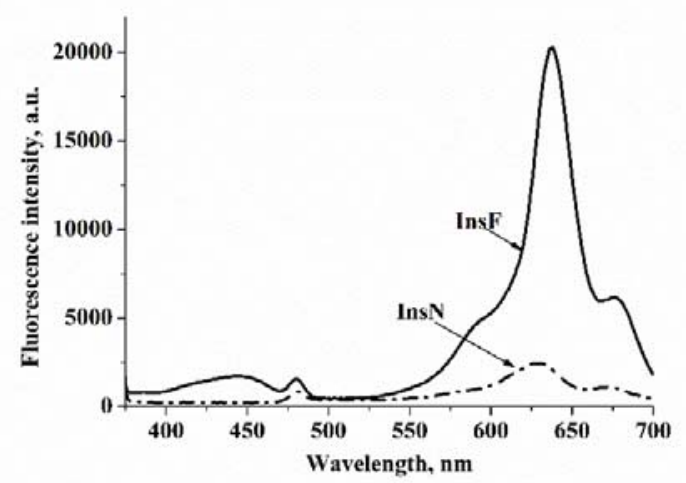

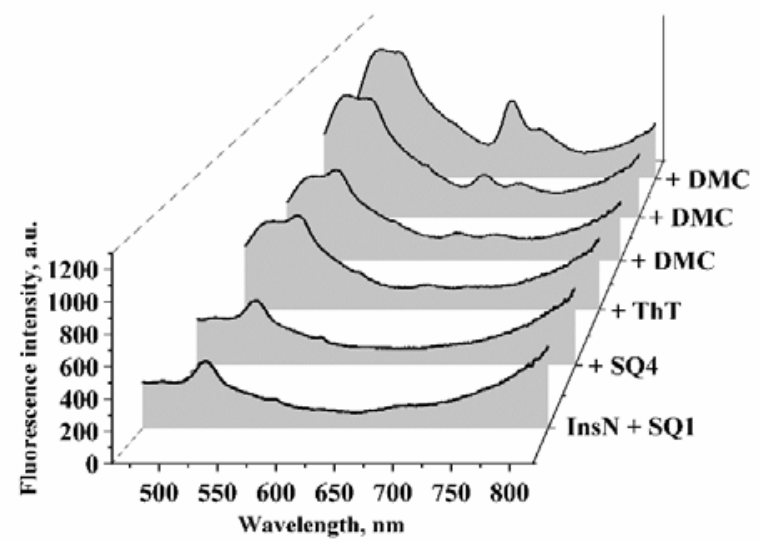

Fig. 4. Changes in the emission spectra of the squaraines (SQ1 and SQ4) upon addition of donors (ThT and DMC) in the presence of the fibrillar (A) and intact (B) protein. Excitation spectra at the highest DMC concentration (C).

The protein concentration was $4.7 \mu \mathrm{M}$. The SQ1-protein mixtures were incubated for two-hours at ambient conditions to to reach the binding equilibrium. SQ1, SQ4 and ThT concentrations were $0.46,0.26$ and $3.58 \mu \mathrm{M}$, respectively. The $\mathrm{DMC}$ concentration was increased from 0.32 to $0.93 \mu \mathrm{M}$.

To quantify the above effects, the enhancement in the fluorescence intensity was calculated as the ratio $I_{i}^{683} / I_{S Q 1}^{683}$ for SQ1, and $I_{i}^{648} / I_{S Q 4}^{648}$ for SQ4 at increasing DMC concentration (Fig. 5), where $I_{i}^{683}$ and $I_{i}^{648}$ are the fluorescence intensities at the $i$-th point of the sample titration with DMC; $I_{S Q 1}^{683}$ and $I_{S Q 4}^{648}$ are the initial fluorescence intensities of the squaraines. As seen in Fig.5, the addition of the donor D1 (ThT) resulted in the SQ1/SQ4 fluorescence enhancement by $6 / 12$ times in the presence of fibrillar insulin and by 1.2/1.6 times in the presence the of the control protein, respectively. The mediator (DMC) led to a further enhancement of the squaraine fluorescence for both fibrillar and the non-fibrillized control protein with respect to that of the mediator-free systems. 
The ratio of the signal amplification in the presence of the fibrillar protein to that in the control showed somewhat decrease with increasing the DMC concentration (Fig. 5C). However, at all mediator concentrations, the dye fluorescence enhancement was more than 3 times stronger in the presence of fibrillar insulin with respect to the control protein for both SQ1 and SQ4.
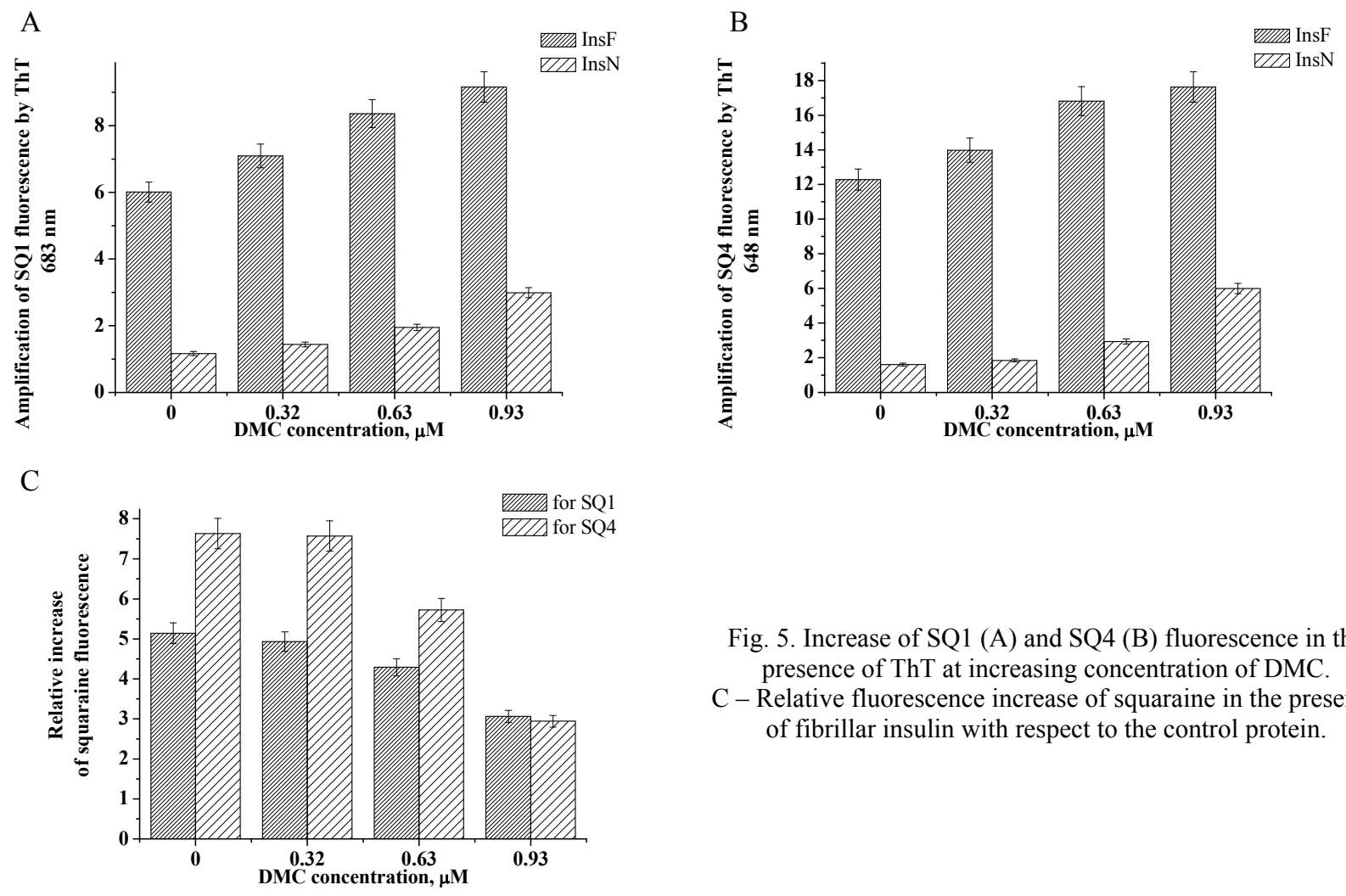

Fig. 5. Increase of SQ1 (A) and SQ4 (B) fluorescence in the presence of ThT at increasing concentration of DMC.

$\mathrm{C}$ - Relative fluorescence increase of squaraine in the presence of fibrillar insulin with respect to the control protein.

A

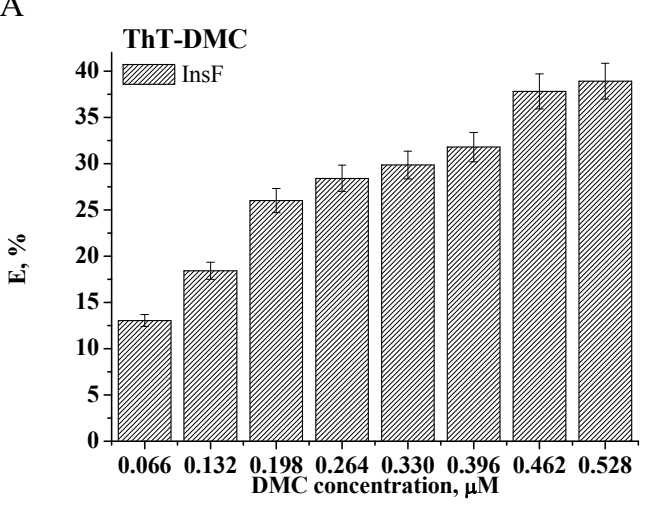

B

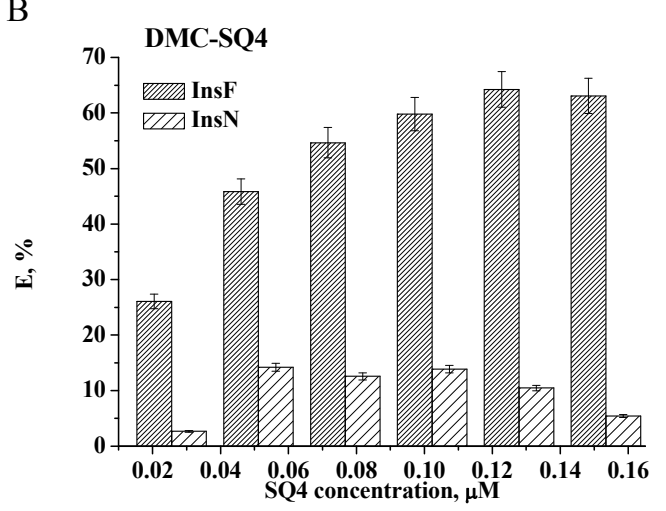

$\mathrm{C}$

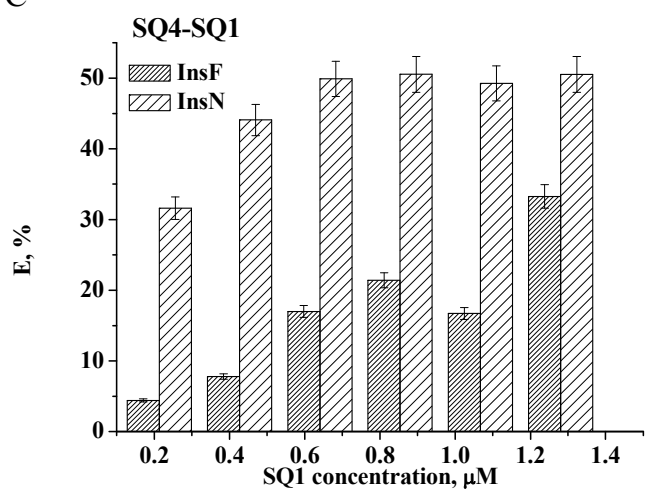

Fig. 6. The FRET efficiencies for the donor-acceptor pairs ThT-DMC (A), DMC-SQ4 (B), SQ4-SQ1 (C) as a function of acceptor concentration.

The protein concentration was $4.9 \mu \mathrm{M}$. ThT concentration was 1.2 $\mu \mathrm{M}$. DMC, SQ4 and SQ1 concentrations are indicated in figures. 
At the next step of the study, the ThT-protein mixtures were consecutively titrated with DMC, SQ4 and SQ1.The donor fluorescence gradually decreased with increasing acceptor concentration for each FRET step in the presence of both fibrillar and control protein, except for the ThT-DMC pair in InsN, where the donor and acceptor fluorescence increased simultaneously due to superposition of the DMC and ThT emission spectra (data not shown). The efficiencies of energy transfer for the three donor-acceptor pairs were calculated from the quenching of the donor fluorescence. As illustrated in Fig. 6, FRET efficiencies in the presence of fibrillar insulin increased with increasing acceptor concentrations by the factors of 3, 2.4 and 7.5 for the pairs ThT-DMC, DMC-SQ4 and SQ4-SQ1, respectively. The largest values of FRET efficiency were observed for the pair DMC-SQ4 $(E>60 \%)$. Remarkably, the energy transfer efficiencies in the presence of fibrillar insulin were $\sim 12$ times greater and $\sim 1.5$ times lower than those for the control protein for the pairs D2-A2 and D3-A3, respectively. A more pronounced FRET observed in the control protein for the pair SQ4-SQ1 as compared to InsF did not have a critical influence on the resulting transfer efficiency, since at the first step of cascade FRET the energy was not transferred in InsN and at the second step the efficiency was lower than that in InsF.

As seen from Eqs. (3) and (4), the efficiency of energy transfer depends on the distance between donor and acceptor and the Förster radius which, in turn, is determined by the overlap between the donor emission and acceptor absorption spectra, the donor quantum yield and the acceptor extinction coefficient, the refractive index of the medium and the orientation factor. The overlap integrals, the Förster radii and the donor-acceptor separations were calculated for the pairs ThT-DMC, DMC-SQ4 and SQ4-SQ1 taking the isotopic value of the orientation factor $\left(\kappa^{2}=2 / 3\right)$.

The relative quantum yield of the donors (Table 1) was calculated as:

$$
Q_{d}=Q_{s} \cdot \frac{\left(1-10^{A_{s}}\right) S_{d} n_{d}{ }^{2}}{\left(1-10^{A_{d}}\right) S_{s} n_{s}^{2}}
$$

where $Q_{s}$ is the quantum yield of the standard, $A_{d}$ and $A_{s}$ are the optical densities at the donor excitation wavelength, $S_{d}$ and $S_{s}$ are the areas under the fluorescence bands, $n_{d}$ and $n_{s}$ are the refractive indexes of the medium for the donor and standard, respectively. Notably, the binding of ThT to fibrillar insulin resulted in the increase of the dye quantum yield by more than two orders of magnitude (Table 1).

Table 1

Donor quantum yields in the presence of fibrillar insulin

\begin{tabular}{|c|c|c|}
\hline Donor & $Q_{d}$ & Standard \\
\hline ThT & 0.02 & ThT in buffer $\left(\mathrm{Q}_{\mathrm{s}}=10^{-4}\right)[39]$ \\
\hline DMC & 0.18 & DMC in ethanol $\left(\mathrm{Q}_{\mathrm{s}}=0.2\right)[40]$ \\
\hline SQ4 & 0.014 & Nile Blue in water $\left(\mathrm{Q}_{\mathrm{s}}=0.01\right)[41]$ \\
\hline
\end{tabular}

The normalized emission and absorption spectra of the three donor-acceptor pairs are depicted in Fig. 7, while the overlap integral value $(J)$ evaluated by the numerical integration are presented in Table 2. The pair SQ1-SQ4 demonstrated the greatest $J$ value due to a small shift $(\sim 32 \mathrm{~nm})$ between SQ4 fluorescence and SQ1 absorption maxima, and a high extinction coefficient of SQ1.

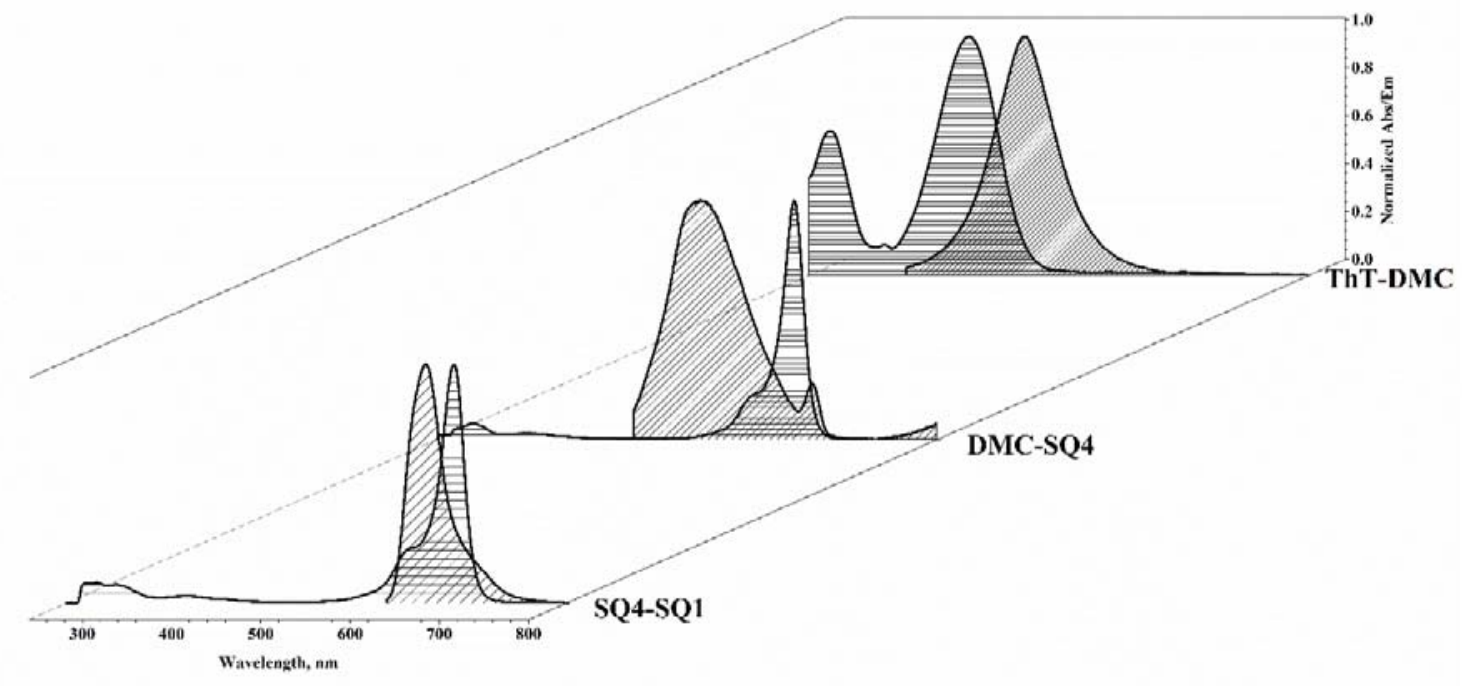

Fig. 7. Overlap of the normalized donor emission (slanting lines) and acceptor absorption (horizontal lines) spectra for the donoracceptor pairs ThT-DMC ( $\left.\lambda_{\max }^{\text {fluor }}=483 \mathrm{~nm}, \lambda_{\max }^{\text {abs }}=421 \mathrm{~nm}\right)$, DMC-SQ4 $\left(\lambda_{\max }^{\text {fluor }}=535 \mathrm{~nm}, \lambda_{\max }^{\text {abs }}=641 \mathrm{~nm}\right)$ and SQ4-SQ1 $\left(\lambda_{\max }^{\text {fluor }}=644 \mathrm{~nm}, \lambda_{\max }^{\text {abs }}=676 \mathrm{~nm}\right)$. 
The Förster radius, a characteristic of each donor-acceptor pair, was calculated from equation (4). The largest value of the Förster radius (Table 2) was obtained for the pair DMC-SQ4 due to the greatest values of DMC relative quantum yield (0.18) and SQ4 extinction coefficient $\left(\varepsilon_{641}^{D M S O}=4.21 \cdot 10^{5} \mathrm{M}^{-1} \mathrm{~cm}^{-1}\right)$. The donor-acceptor distance $r$ was estimated based on the classical expression for the distance dependence of FRET efficiency (Eq. 3) using the $E$ values at the maximum acceptor concentrations.

Table 2

FRET parameters obtained under assumption of isotopic rotation of the fluorophores

\begin{tabular}{|c|c|c|c|}
\hline System & $J, \mathrm{M}^{-1} \mathrm{~cm}^{-1} \mathrm{~nm}^{4}$ & $R_{0}, \mathrm{~nm}$ & $r, \mathrm{~nm}$ \\
\hline ThT-DMC & $3.73 \cdot 10^{14}$ & 2.3 & 2.4 \\
\hline DMC-SQ4 & $5.32 \cdot 10^{15}$ & 5.0 & 4.5 \\
\hline SQ4-SQ1 & $1.52 \cdot 10^{16}$ & 3.9 & 4.3 \\
\hline
\end{tabular}

The distinctions between the fibrillar and control proteins appeared to be the most pronounced in the 3D fluorescence spectra. As illustrated in Fig. 8A, in the system consisting of ThT, DMC and SQ4 bound to InsF, the strongest fluorescence centered around $\sim 650 \mathrm{~nm}$ corresponds to SQ4; the spot located above the excitation wavelength $550 \mathrm{~nm}$ is related to the direct excitation of SQ4, while the bottom spot centered at $\lambda_{\mathrm{Ex}} \sim 440 \mathrm{~nm}$ originates from the energy transfer $\mathrm{ThT} \rightarrow \mathrm{DMC} \rightarrow \mathrm{SQ} 4$. A residual ThT fluorescence is observed at $\lambda_{\mathrm{Ex}} \sim 440 \mathrm{~nm}$ and $\lambda_{\mathrm{Em}} \sim 580 \mathrm{~nm}$. The addition of SQ1 into the above ternary system resulted in the appearance of a new spot centered at $\lambda_{\mathrm{Em}} \sim 685 \mathrm{~nm}$ and $\lambda_{\mathrm{Ex}} \sim 440 \mathrm{~nm}$, and in the decrease of SQ4 signal (Fig. 8C), suggesting that the energy is transferred from ThT to SQ1 via SQ4. As seen in Figs. 8B and $8 \mathrm{D}$, the intensity of the analogous patterns is substantially lower in InsN compared to InsF. The barely noticeable spots centered at the SQ4 (Fig. 8B) and SQ1 (Fig. 8D) emission maxima at $\lambda_{\mathrm{Ex}} \sim 440 \mathrm{~nm}$ were observed, while the higher emission intensities observed at $\lambda_{\mathrm{Ex}}>550 \mathrm{~nm}$ are related to the direct excitation of the fluorophores.
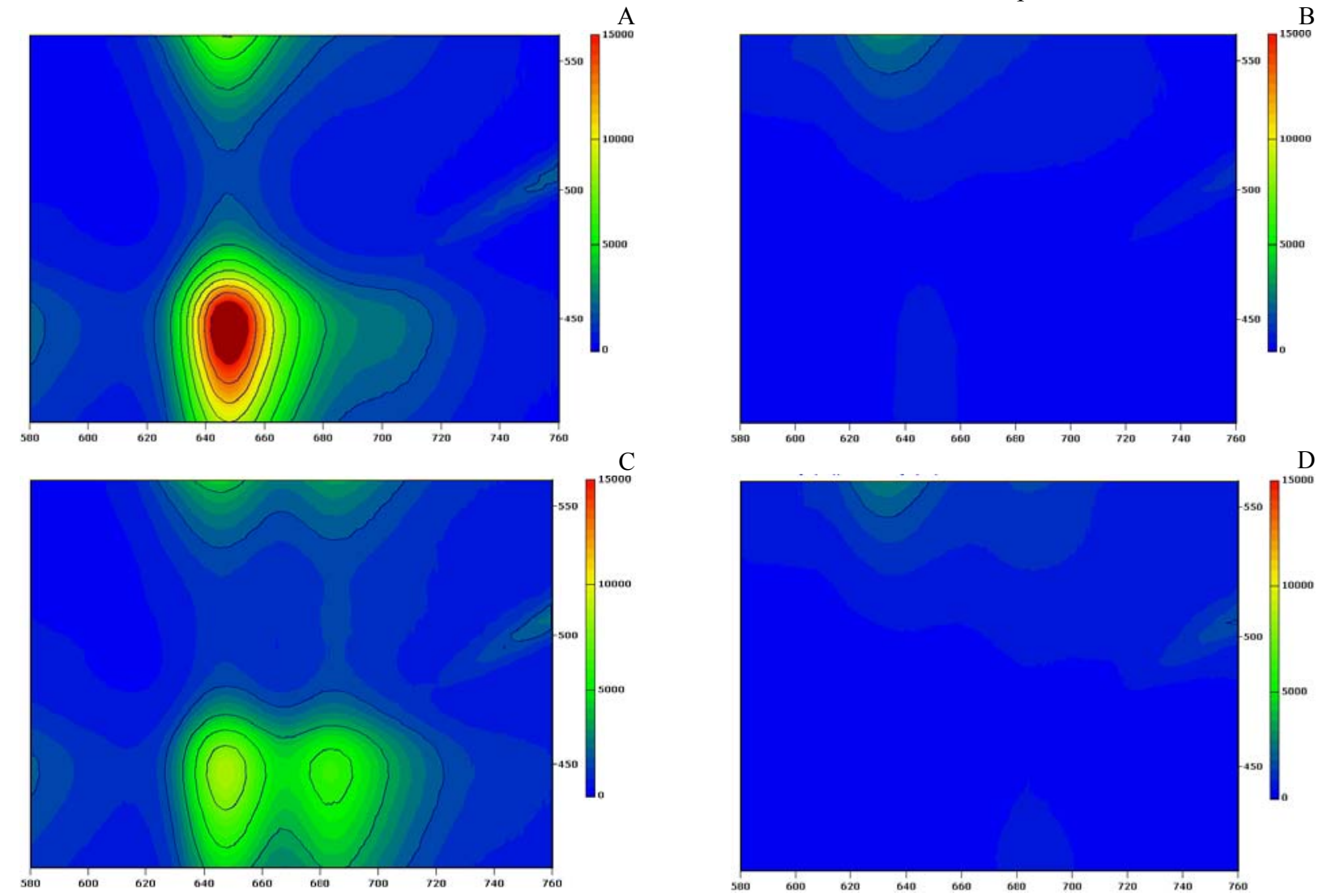

Fig. 8. 3D fluorescence spectra recorded in the presence of DMC $(0.53 \mu \mathrm{M})$ and SQ4 $\left(0.16^{640} \mu \mathrm{M}\right)$ in the ThT - fibrillar $(\mathrm{A})$ and control (B) protein mixtures, followed by the addition of SQ1 $(1.4 \mu \mathrm{M})$ to the fibrillar (C) and control (D) insulin. The emission and excitation wavelengths were varied within the ranges $580-760 \mathrm{~nm}$ and $410-560 \mathrm{~nm}$, respectively. The excitation and emission slit widths were set at $10 \mathrm{~nm}$. The protein and ThT concentrations were 4.9 and $1.2 \mu \mathrm{M}$, respectively.

In the last step of our investigation, the simple docking studies were performed to provide additional structural characterization of the dye-fibril complexes. As seen in Fig. 9A, ThT, DMC and SQ4 tend to associate with the 4-5 residues of the L17 ladder of the insulin fibril protofilament located on the dry steric zipper interface, suggesting the predominant role of hydrophobic and van der Waals dye-protein interactions. A similar binding motif was previously proposed for ThT [42]. In turn, the bulky moieties of zwitterionic SQ1 seem to prevent its binding to the dry amyloid 
surface, and thus, SQ1, being the most hydrophobic among the examined dyes (possessing the highest $\log P$ value, Table 3) binds to the wet surface groove formed by the residues GLN15 and GLU17 of the insulin A-chain. In this case, the hydrophobic, aromatic and electrostatic forces may stabilize the dye-protein complex. Interestingly, the distance between fibril-bound SQ4 and SQ1 was about $3 \mathrm{~nm}$, being close to the value $c a .3 .9 \mathrm{~nm}$ obtained from the FRET efficiency (Table 2).

However, precise identification of the fibril binding sites for the dyes seem to be complicated because the rigid docking algorithms used here are based on the shape complementarity principles (PatchDock) and perform only the protein side-chain optimization (FireDock). In turn, the ligand structure remains fixed during the docking process that may lead to the appearance of the false protein binding sites if the optimized dye geometry used for calculations differs from the real geometry. Thus, the discrepancies between ThT-DMC, and DMC-SQ4 distances obtained experimentally (Table 2) and by the molecular docking (Fig. 9A) can be explained by the drawbacks of the docking technique. To

Table 3

Quantum-chemical characteristics of the dyes after geometry optimization (PM6, MOPAC)

\begin{tabular}{|c|c|c|c|c|}
\hline Dye & SQ1 & SQ4 & DMC & ThT \\
\hline$C A, \AA^{2}$ & 611 & 438 & 304 & 318 \\
\hline$C V, \AA^{3}$ & 767 & 519 & 320 & 350 \\
\hline$E_{\text {HОМО }}, \mathrm{eV}$ & -6.9 & -6.8 & -8.3 & -11.0 \\
\hline$E_{\text {LUMO }}, \mathrm{eV}$ & -2.0 & -1.9 & -0.7 & -4.4 \\
\hline$L, \AA$ & 21.1 & 18.5 & 14.4 & 14.3 \\
\hline$W, \AA$ & 10.7 & 6.4 & 5.7 & 5.7 \\
\hline$H, \AA$ & 8.1 & 4.5 & 3.4 & 3.7 \\
\hline$\mu_{g}, \mathrm{D}$ & 3.2 & 5.8 & 5.7 & 2.7 \\
\hline$M . w t ., \mathrm{g} / \mathrm{M}$ & 608.82 & 424.54 & 251.33 & 188.61 \\
\hline$L o g P$ & 9.81 & 1.59 & 3.84 & -0.14 \\
\hline
\end{tabular}

correlate the FRET and docking results, one should assume that SQ4 and SQ1 are bound to the wet insulin protofilament surface (because of their similar structure), while DMC and ThT reside at the dry amyloid surface due to their small volumes and molecular weights (Table 3). If SQ4 and SQ1 are associated with the two opposite sides of the fibril surface, the intermolecular distance will be about $3 \mathrm{~nm}$. In turn, if ThT and DMC are bound to the L17 ladders available on the first and second $\beta$-sheet of the insulin protofilament, respectively, the distance between the two fluorophores will be about $2.5 \mathrm{~nm}$ (Table 2).

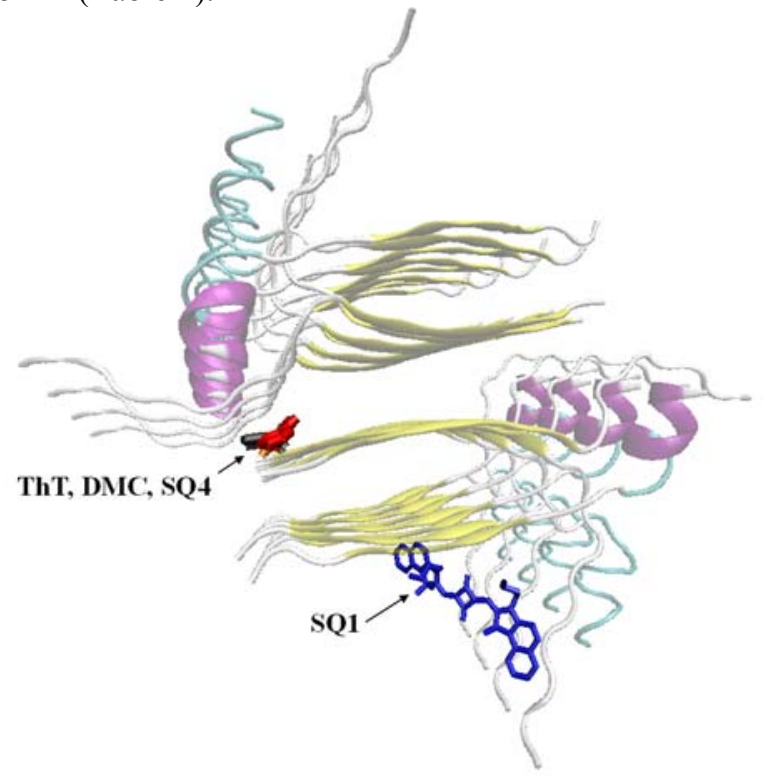

A

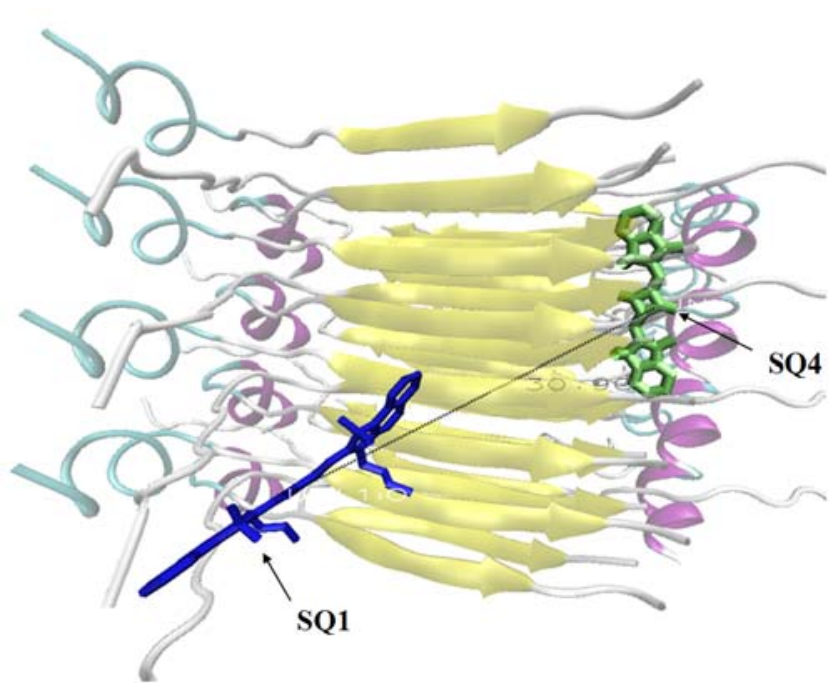

B

Fig. 9. Schematic representation of the energetically most favorable dye complexes with fibrillar insulin, obtained using PatchDock/ FireDock servers and visualized by VMD software.

The drawing method was set as Bonds and NewCartoon for the dyes and the protein, respectively. ThT, DMC, SQ4 are bound to the L17 ladder of the B chain, located at the dry steric zipper of the insulin fibril protofilament, while SQ1 is attached to the surface groove formed by the residues GLN15 and GLU17 of the A chain (A). The distance between SQ1 and SQ4 is about $3 \mathrm{~nm}$ (B). 


\section{CONCLUSIONS}

To summarize, we have successfully designed the dye ensemble suitable for the three-step sequential FRET in the insulin amyloid fibrils. The following chromophores were recruited as the components of the fibril-scaffolded FRET chain: i) a primary donor, Thioflavin T, transferring its energy to the mediator dye, DMC, upon excitation at $440 \mathrm{~nm}$; ii) a novel squaraine dye SQ4 accepting the energy from DMC; and iii) squaraine fluorophore SQ1 accepting the energy from SQ4, followed by the emission enhancement at $680 \mathrm{~nm}$. The above cascade showed notable increase in the SQ1 fluorescence compared to that devoid of DMC. Despite the parallel FRET between the dyes cannot be excluded, the donor-acceptor distances estimated for each pair assuming the isotopic chromophore rotation appeared to be consistent with the intergroove separations in the core of insulin fibrils. The recovered distances fall in the range $2.4-4.5 \mathrm{~nm}$, suggesting different fibril binding sites for the dyes. The fact that no cascade FRET was observed in the non-fibrillized protein, highlights the importance of the dye association with the highly ordered amyloid structure for the energy transfer to occur in the chain $\mathrm{ThT} \rightarrow \mathrm{DMC} \rightarrow \mathrm{SQ} 4 \rightarrow \mathrm{SQ} 1$. These results may prove of importance in the development of the novel sensitive fluorescence approaches to amyloid detection and characterization, particularly, in vivo, by introducing the nearinfrared fluorophores to the cascade.

\section{ACKNOWLEDGEMENTS}

This work was supported by the Ministry of Education and Science of Ukraine (the Young Scientist project № 0117 U004966 "Nano- and microsized liophylic and liophylized self-associated systems: application in modern technologies and biomedicine", the project № 0119U002525 “Development of novel ultrasonic and fluorescence techniques for medical micro- and macrodiagnostics”), and the President’s of Ukraine grant for the Young Scientists № 0119U103453 “Design of multifunctional drug nanocarriers based on the liposomes and protein hydrogels").

\section{ORCID IDs}

-Uliana Tarabara https://orcid.org/0000-0002-7677-0779, (- Kateryna Vus https://orcid.org/0000-0003-4738-4016, OOlga Zhytniakivska https://orcid.org/0000-0001-9554-0090, (DValeriya Trusova https://orcid.org/0000-0002-7087-071X, CGalyna Gorbenko https://orcid.org/0000-0002-0954-5053

\section{REFERENCES}

[1] P. Wu and L. Brand, Anal. Biochem. 218, 1-13 (1994), https://doi.org/10.1006/abio.1994.1134.

[2] P.R. Selvin, Nature Struct. Biol. 7, 730-734 (2000), https://doi.org/10.1038/78948.

[3] L.M. Loura and M. Prieto, Front. Physiol. 2, 82 (2011), https://doi.org/10.3389/fphys.2011.00082.

[4] G. Ramanoudjame, M. Du, K.A. Mankiewicz and V. Jayaraman, Proc. Natl. Acad. Sci. U.S.A. 103, 10473-10478 (2006), https://doi.org/10.1073/pnas.0603225103.

[5] A. Coskun and E.U. Akkaya, J. Am. Chem. Soc. 128, 14474-14475 (2006), https://doi.org/10.1021/ja066144g.

[6] P. Tinnefeld, M. Heilemann and M. Sauer, Chem. Phys. Chem 6, 217-222 (2005), https://doi.org/10.1002/cphc.200400513.

[7] B. Albinsson, J.K. Hannestad and K. Borjesson, Coordination Chemistry Reviews, 256, 2399-2413 (2012), https://doi.org/10.1016/j.ccr.2012.02.024.

[8] S. Buckhout-White, C.W. Brown III, D.A. Hastman Jr, M.G. Ancona, J.S. Melinger, E.R. Goldmana and I.L. Medintz, RSC Adv. 6, 97587-97598 (2016), https://doi.org/10.1039/C6RA23079B.

[9] A. Bodi, K.E. Borbas and J.I. Bruce, Dalton Trans. 2007, 4352-4358 (2007), https://doi.org/10.1039/B708940F.

[10] D. Navarathne, Y. Ner, J.G. Grote and G.A. Sotzing, Chemical Communications, 47, 12125-12127 (2011), https://doi.org/10.1039/C1CC14416B.

[11] G. McDermott, S.M. Prince, A.A. Freer, A.M. Hawthornthwaite-Lawless, M.Z. Papiz, R.J. Cogdell and N.W. Isaacs, Nature, 374, 517-521 (1995), https://doi.org/10.1038/374517a0.

[12] W. Kühlbrandt and D.N. Wang, Nature, 350, 130-134 (1991), https://doi.org/10.1038/350130a0.

[13] C. Goze, G. Ulrich and R. Ziessel, J. Org. Chem. 72, 313-322 (2007), https://doi.org/10.1021/jo060984w.

[14] J. Saha, D. Dey, A.D. Roy, P. Bhattacharjee and S.A. Hussain, J. Luminesc. 172, 168-174 (2016), https://doi.org/10.1016/j.jlumin.2015.12.004.

[15] G. Ulrich, C. Goze, M. Guardigli, A. Rodda and R. Ziessel, Angew. Chem. Int. Ed. 44, 3694-3698 (2005), https://doi.org/ 10.1002/anie.200500808.

[16] A. Aneja, N. Mathur, P.K. Bhatnagar and P.C. Mathur, J. Biol. Phys. 34, 487-493 (2008), https://doi.org/10.1007/s10867-0089107-y.

[17] K. Boeneman, D.E. Prasuhn, J.B. Blanco-Canosa, P.E. Dawson, J.S. Melinger, M. Ancona, M.H. Stewart, K. Susumu, A. Huston and I.L. Medintz, Proc. of SPIE, 7909, 1-7 (2011), https://doi.org/10.1117/12.879272.

[18] R.W. Wagner and J.S. Lindsey, J. Am. Chem. Soc. 116, 9759-9760 (1994), https://doi.org/10.1021/ja00100a055.

[19] R.W. Wagner, J.S. Lindsey, J. Seth, V. Palaniappan and D.F. Bocian, J. Am. Chem. Soc. 118, 3996-3997 (1996), https://doi.org/10.1021/ja9602657.

[20] X. Song, J. Shi, J. Nolan and B. Swanson, Anal. Biochem. 291, 133-141 (2001), https://doi.org/10.1006/abio.2001.5024.

[21] X. Duan, S. Wang and Z. Li, Chem. Commun. 2008, 1302-1304 (2008), https://doi.org/10.1039/B717300H.

[22] V. Raicu, J. Biol. Phys. 33, 109-127 (2007), https://doi.org/10.1007/s10867-007-9046-z.

[23] L. He, X. Wu, J. Simone, D. Hewgill and P.E. Lipski, Nucleic Acid Res. 33, 61-73 (2005), https://doi.org/10.1093/nar/gni057.

[24] E. Galperin, V. V. Verkhusha and A. Sorkin, Nature Methods, 1, 209-217 (2004), https://doi.org/10.1038/nmeth720.

[25] G. Gorbenko, V. Trusova, T. Deligeorgiev, N. Gadjev, C. Mizuguchi and H. Saito, J. Mol. Liq. 294, 111675 (2019), https://doi.org/10.1016/j.molliq.2019.111675.

[26] M. Kuscu and O.B. Akan, IEEE Transactions on nanotechnology, 11, 200-207 (2012), https://doi.org/10.1109/ TNANO.2011.2170705. 
[27] G. Bunt and F.S. Wouters, Biophys. Rev. 9, 119-129 (2017), https://doi.org/10.1007/s12551-017-0252-z.

[28] B.W. Meer, D.M. Meer and S.S. Vogel, in: FRET - Förster Resonance Energy Transfer: From Theory to Applications, edited by I.L. Medintz and N. Hildebrandt (Wiley-VCH, Weinheim, 2014), pp. 63-104, https://doi.org/10.1002/9783527656028.ch04.

[29] J.R. Lakowicz, Principles of fluorescence spectroscopy, 3rd ed., (Springer, New York, 2006), pp. 445-453.

[30] L. Stryer, Annual review of biochemistry, 47, 819-846 (1978), https://doi.org/10.1146/annurev.bi.47.070178.004131.

[31] Z. Gryczynski, I. Gryczynski and J.R. Lakowicz, in: Molecular imaging: FRET microscopy and spectroscopy, edited by A. Periasamy, R. Day (Qxford, New York, 2005), pp. 19-56.

[32] B. Valeur, Molecular fluorescence: principles and applications, (Wiley-VCH, Weinheim, 2001), pp. 247-272, https://doi.org/10.1002/3527600248.ch9.

[33] H.M. Watrob, C.P. Pan and M.D. Barkley, J. Am. Chem. Soc. 125, 7336-7343 (2003), https://doi.org/10.1021/ja034564p.

[34] M. Groenning, J. Chem. Biol. 3, 1-18 (2010), https://doi.org/10.1007/s12154-009-0027-5.

[35] M.I. Ivanova, S.A. Sievers, M.R. Sawaya, J.S. Wall and D. Eisenberg, Proc. Natl. Acad. Sci. USA. 106, 18990-19995 (2009), https://dx.doi.org/10.1073\%2Fpnas.0910080106.

[36] J.J. Stewart, J. Comput. Aided. Mol. Des. 4, 1-105 (1990), https://doi.org/10.1007/BF00128336.

[37] D. Duhovny, R. Nussinov, H.J. Wolfson, Lect. Notes Comput. Sci. Eng. 2452, 185-200 (2002), https://doi.org/10.1007/3-54045784-4_14.

[38] I.V. Tetko and V.Y. Tanchuk, J. Chem. Inf. Comput. Sci. 42, 1136-1145 (2002), https://doi.org/10.1021/ci025515j.

[39] A.I. Sulatskaya, A.A. Maskevich, I.M. Kuznetsova, V.N. Uversky and K.K. Turoverov, PLoS ONE, 5, e15385 (2010), https://doi.org/10.1371/journal.pone.0015385.

[40] J.A. Vladimirov and G.E. Dobretsov, Флуоресиентные зонды в исследовании биологических мембран [Fluоrescent probes in study of biological membranes], (Nauka, Moscow, 1980), pp. 40. (in Russian)

[41] H.P. Oliveira, A.J. Camargo, L.G. Macedo, M.H. Gehlen and A.B. da Silva, Spectrochim. Acta A Mol. Biomol. Spectrosc. 58, 3103-3111 (2002), https://doi.org/10.1016/S1386-1425(02)00119-1.

[42] K. Vus, M.Girych, V. Trusova, G. Gorbenko, A. Kurutos, A. Vasilev, N. Gadjev and T. Deligeorgiev, Journal of Molecular Liquids, 276, 541-552 (2019), https://doi.org/10.1016/j.molliq.2018.11.149.

ТРЬОХЕТАПНИЙ РЕЗОНАНСНИЙ ПЕРЕНОС ЕНЕРГІЇ В АМІЛОЇДНИХ ФІБРИЛАХ ІНСУЛІНУ У. Тарабара ${ }^{1}$, М. Щука ${ }^{1}$, К. Вус ${ }^{1}$, О. Житняківська ${ }^{1}$, В. Трусова ${ }^{1}$, Г. Горбенко, Н. Гаджев ${ }^{2}$, Т. Делігеоргісв

${ }^{1}$ Кафедра медичної фізики та біомедичних нанотехнологій,

Харківський національний університет імені В.Н. Каразіна пл. Свободи 4, Харків, 61022, Украӥна

${ }^{2}$ Факультет хімії і фармаиії, Софійський університет, Софія, 1164, Болгарія

За допомогою системи хромофорів, що складалась із тіофлавіну Т (ThT), 4-диметиламінохалкону (ДМХ) і двох сквараїнових барвників, SQ1 і SQ4, проведено оцінку можливості використання трьохетапного індуктивно-резонансного переносу енергії (IPПЕ) для детектування амілоїдних фібрил інсуліну. Виявлено, що медіаторний барвник ДМХ збільшує інтенсивність флуоресценції кінцевого акцептора SQ1, що збуджується на 440 нм (у максимумі поглинання основного донора, ThT), у фібрилярному інсуліні, у порівнянні з флуоресценцією у відсутності ДМХ, що свідчить про наявність каскадного переносу енергії вздовж ланцюга ThT $\rightarrow$ ДМX $\rightarrow \mathrm{SQ} 4 \rightarrow \mathrm{SQ} 1$. Окрім цього, Стоксовий зсув у системі з чотирма хромофорами складав 240 нм, у порівнянні з 45 нм для зв'язаного з амілоїдними фібрилами тіофлавіну Т, що свідчить про перевагу детектування амілоїдних фібрил за допомогою багатоетапного ІРПЕ завдяки вищому співвідношенню сигнал-шум. Максимальні значення ефективності переносу енергії в фібрилах інсуліну, визначені для кожної каскадної пари при вимірюванні гасіння флуоресценції донора в присутності акцептора, складали 40\%, 60\% і 30\% для донорно-акцепторних пар ThT-ДMX, ДMX-SQ4 i SQ4-SQ1, відповідно, , тоді як у випадку нефібрилізованого білка перенос енергії був практично відсутній. Найбільш виражені відмінності між фібрилярним та нефібрилізованим білком спостерігались в 3D спектрах флуоресценції. Зокрема, у фібрилярних агрегатах інсуліну виявлено дві інтенсивні області з центрами на довжинах хвиль флуоресценції 650 нм (SQ4) та $\sim 685$ нм (SQ1) при збудженні на довжині хвилі $\sim 40 \mathrm{~nm}$. Натомість, для нефібрилізованого білка, були наявні ледь помітні області на тих самих довжинах хвиль, а також, більш інтенсивні області при збудженні на довжині хвилі понад 550 нм, що свідчить про переважний вплив прямого збудження SQ1 та SQ4 на флуоресцентну відповідь зондів. Міжмолекулярні відстані, розраховані на основі експериментальних значень ефективності переносу енергії у припущенні ізотропного обертання хромофорів, становили 2.4, 4.5 і 3.2 нм для пар ThT-ДМХ, ДMX-SQ4 і SQ4-SQ1, відповідно, що свідчить про різні сайти зв'язування барвників з фібрилами. Квантово-хімічні розрахунки і метод молекулярного докінгу дозволили припустити, що зв'язування SQ1, SQ4 і ThT, ДМХ відбувається з «вологою» і «сухою» поверхнями протофіламентів інсуліну, відповідно. Комплекси зонд-білок, вочевидь, стабілізуються гідрофобними, ван-дер-Ваальсовими, ароматичними та електростатичними взаємодіями. Таким чином, завдяки високій чутливості та нижчій вірогідності псевдо-позитивного результату, розроблений метод можна використовувати для детектування та характеризації амілоїдних фібрил in vitro паралельно 3 класичним тіофлавіновим методом. Перспективним також $є$ використання багатоетапного IPПЕ для візуалізації амілоїдів in vivo, за умови включення до каскаду зонду, що має смуги поглинання і флуоресценції у ближній інфрачервоній області.

КЛЮЧОВІ СЛОВА: каскадний резонансний перенос енергії, 4-диметиламінохалкон, фібрилярний інсулін, сквараїнові зонди, тіофлавін Т.

ТРЕХЭТАПНЫЙ РЕЗОНАНСНЫЙ ПЕРЕНОС ЭНЕРГИИ В АМИЛОИДНЫХ ФИБРИЛЛАХ ИНСУЛИНА У. Тарабара ${ }^{1}$, М. Щука ${ }^{1}$ К. Вус ${ }^{1}$, О. Житняковская ${ }^{1}$, В. Трусова ${ }^{1}$, Г. Горбенко ${ }^{1}$ Н. Гаджев ${ }^{2}$, Т. Делигеоргиев ${ }^{2}$ ${ }^{1}$ Кафедра медицинской физики и биомедицинских нанотехнологий, Харьковский начиональный университет имени В.Н. Каразина пл. Свободы 4, Харьков, 61022, Украина

${ }^{2}$ Факультет химии и фармации, Софийский университет, София, 1164, Болгария

С помощью системы хромофоров, содержащей тиофлавин Т (ThT), 4-диметиламинохалкон (ДМХ) и два сквараиновых красителя, SQ1 и SQ4, проведена оценка возможности использования трехэтапного индуктивно-резонансного переноса энергии (ИРПЕ) для детектирования амилоидных фибрилл инсулина. Обнаружено, что медиаторный краситель ДМХ 
увеличивает интенсивность флуоресценции конечного акцептора SQ1, возбуждаемого при 440 нм (в максимуме поглощения основного донора, ThT), в фибриллярном инсулине по сравнению с флуоресценцией в отсутствие ДМХ, что свидетельствует о наличии каскадного переноса энергии вдоль цепи $\mathrm{ThT} \rightarrow Д \mathrm{MX} \rightarrow \mathrm{SQ} 4 \rightarrow \mathrm{SQ} 1$. Кроме того, Стоксов сдвиг в системе с четырьмя хромофорами составил 240 нм, по сравнению с 45 нм для тиофлавина Т, связанного с амилоидными фибриллами, что свидетельствует о преимуществе детектирования амилоидных агрегатов при помощи многоэтапного ИРПЕ благодаря более высокому отношению сигнал-шум. Максимальные значения эффективности переноса энергии в фибриллах инсулина, определенные для каждой каскадной пары при измерении тушения флуоресценции донора в присутствии акцептора, составили 40\%, 60\% і 30\% для донорно-акцепторных пар ThT-ДМХ, ДМХ-SQ4 и SQ4-SQ1, соответственно, тогда как в случае нефибриллизованого белка перенос энергии практически отсутствовал. Наиболее выраженные различия между фибриллярным и нефибрилизованным белком наблюдались в 3D спектрах флуоресценции. В частности, в амилоидных агрегатах инсулина обнаружено две интенсивных области с центрами на длинах волн эмиссии $\sim 650$ Hм (SQ4) и $\sim 685$ нм (SQ1) при возбуждении на длине волны $\sim 440$ нм. В свою очередь, для нефибрилизованного белка выявлены едва заметные области с центрами на тех же самых длинах волн, а также - области с более высокими интенсивностями при возбуждении выше 550 нм, что свидетельствует о преимущественном влиянии прямого возбуждения SQ1 и SQ4 на флуоресцентный ответ этих красителей. Межмолекулярные расстояния, рассчитанные на основе экспериментальных значений эффективности переноса энергии, составили 2.4, 4.5 и 3.2 нм для пар ThT-ДМХ, ДМХ-SQ4 и SQ4-SQ1, соответственно, указывая на различные сайты связывания красителей с фибриллами. Квантово-химические расчеты и метод молекулярного докинга позволили предположить, что связывание SQ1, SQ4 и ThT, ДМХ проиходит с «влажной» и «сухой» поверхностями протофиламентов инсулина, соответственно. Комплексы зонд-белок, по-видимому, стабилизируются,гидрофобными, ван-дер-Ваальсовыми, ароматическими и электростатическими взаимодействиями. Таким образом, благодаря высокой чувствительности и более низкой вероятности псевдо-положительного результата, разработанный метод можно использовать для детектирования и характеризации амилоидных фибрилл in vitro параллельно с классическим тиофлавиновым методом. Перспективной является также оценка возможности использования многоэтапного ИРПЕ для визуализации амилоидов in vivo, при условии включения в каскад зонда, который имеет полосы поглощения и испускания в ближней инфракрасной области.

КЛЮЧЕВЫЕ СЛОВА: каскадный резонансный перенос энергии, 4-диметиламинохалкон, фибриллярный инсулин, сквараиновые зонды, тиофлавин Т. 